\title{
OBSERVATIONS ON THE ANTI-TRUST LAWS, ECONOMIC THEORY AND THE SUGAR INSTITUTE DECISIONS: I
}

\section{JAMES LAWRENCE FLY†}

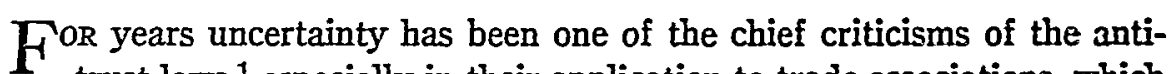
trust laws, ${ }^{1}$ especially in their application to trade associations, which have become the form of combination most characteristic of the present stage in American industrial organization. These complaints frequently cloak an aversion to the settled areas of the law. ${ }^{1}$ But business men and many of their lawyers looked forward to the Supreme Court's decision in the Sugar Institute case ${ }^{2}$ in the hope that it would mark out with greater certainty the legitimate field in which such business associations might operate. Thus, one able commentator on anti-trust subjects, writing on the eve of the Supreme Court's decision, expressed the expectation that the Court's decision might be "both a charter of liberties and an index expurgatorius for the trade association movement." ${ }^{23}$ The case presented for review the most comprehensive system of trade association activities ever examined by the courts. There was an opportunity for detailed certainty of such an abstract sort that major principles themselves might easily have been engulfed.

The suit was brought by the Government under Section 1 of the Sherman Act to enjoin the activities of the Sugar Institute, a trade association composed of fifteen sugar refiners who produced virtually all of the refined cane sugar consumed in the United States. The activities of the Institute commenced early in 1928 and involved, among other things, detailed statistical services, including price reporting, agreements prohibiting or regulating numerous competitive devices, agreements as to freight rates, and agreements regulating processes of distribution. In an exhaustive and detailed opinion, the trial court, finding the alleged

i General Solicitor, Tennessee Valley Authority, Special Assistant to the Attorney General in the trial of the Sugar Institute case.

1. Cf. Montague, Proposals for the Revision of the Anti-trust Laws (1932) Syarosrons on tHe Federat ANTI-TRUST LAws, C. C. H. 23, 29; Handler, The Sugar Instilute Case and the Present Status of the Anti-trust Laws (1936) 36 Cor. L. Rxv. 1, 18; and see Donovan, The Effect of the Decision in the Sugar Institute Case upon Trade Association Activitis (1936) 84 U. of PA. L. REv. 929.

2. Sugar Institute, Inc. v. United States, 56 S. Ct. 629 (1936).

3. Handler, loc. cit. supra note 1 , at 1 . 
justification for these activities without foundation in fact, issued an injunction against most of them. The Supreme Court affirmed the decree with relatively minor modifications, including a modification to permit a limited scheme of future price reporting. Judge Mack's opinion in the trial court is the most careful study on record of an actual system of restraints. The treatment of the specific items in his opinion, the quality of his conclusions of law, and the specific injunctive provisions are of greatest utility in arriving at specific predictions. While a more thorough and expressive review of the case in the Supreme Court would have been desirable, nevertheless the case in the main is distinguished by a sense of practical realism, and a willingness to stick closely to facts, which seems to make the law march toward a sounder and clearer formulation.

The decision must have disappointed some at least of the trade association lawyers, because the Supreme Court refused to commit itself in advance to a catalog of fixed judgments on the legality of particular trade association practices. But there is a substantial sense in which the opinion may clarify the law. For, if the law is certain when the Bar can know the technique which courts will use in the process of fitting future cases into the framework of doctrine, the Sugar Institute case, rend against its background, is a Restatement aimed at certainty.

Perfect and Monopolistic Competition. But before one endeavors to fit the results of the Sugar Institute case into the body of the anti-trust laws, it is desirable to make explicit the economic standards in terms of which both trade practices and legal rules to govern them should be assessed and criticised. It is said that the law forbids "unreasonable" restraints of trade. ${ }^{4}$ The task of determining what are "unreasonable" restraints is a complicated one, and the economist should be able to give the courts helpful testimony.

The law supports the social policy of competition, in the conviction that it provides the public with more goods at lower prices; affords opportunities for new producers to enter industry; encourages efficiency; and, by preserving a measure of flexibility in the economic system, makes the swings of the credit cycle shorter and less onerous. Monopoly is regarded as an ancient and familiar evil, not only in that it allows one part of the community to exact tribute from another, but because it reduces the total of production and interposes a real barrier in the way of expansion. "Restriction in these circumstances means, then, gain to

4. Cf. the development of the doctrine of reasonableness from United States v. IransMissouri Freight Assn., 166 U. S. 290 (1897) and Mr. Chief Justice Taft's theory that ancillary restraints might be lefgal, United States v. Addyston Pipo and Stcel Co., 85 Fed. 271 (C. C. A. 6th, 1898), aff'd 175 U. S. 211 (1899), through Standard Oll Co. v. United States, 221 U. S. 1 (1911); United States v. American Tobacco Co., 221 U. S. 106 (1911); Paramount Famous Lasky Corp. v. United States, 282 U. S. 30 (1930). 
one part of the community at the expense of a more than equivalent loss to other parts."

The economic analysis of the monopolistic behavior of trade associations, as typical instruments of contemporary collective action among sellers, is complicated by the prevalence in the literature of concepts rich with a magic ambiguity, like "stabilization of prices," "cut-throat competition," "unethical trade practices," and "excess capacity." If one can confine the discussion within the limits of economic fact, the main outlines of the trade association problem, as it concerns competition and the laws protecting competition, become relatively clear.

Economic analysis of trade association activities has too often been carried through in terms of pure or perfect competition, without regard to the characteristics of the modern monopolistic market. For example, when price uniformity appears, there is an uncritical tendency to account for it as a consequence of perfect competition, despite the substantial impediments to the practical application of that theory in many markets. Frequently, with greater logic, such a result must be attributed to forces which older economists dismissed impatiently as monopolistic interference with perfect competition, and which a newer literature of analysis characterizes as monopolistic competition. ${ }^{B}$ The ides of perfect competition in economic theory is a useful abstraction which has contributed mightily to the clarification of economic doctrine; but conclusions based on the study of perfect competition cannot be applied to practical market problems without first removing the unrealistic as-

5. Pigod, Econonics If Practice (1935) 135. For the effect of price stabilization achieved by monopolistic action in making the swings of the trade cycle more intencs, $\mathrm{cf}$. BURNs, op. cit. infra note 6 at 271-272; RoBbLrs, op. cit. infra note 11; Hurser, Eco:iosnc Stabilization In an Unbalanced WorLd (1932).

6. For the general literature on this subject, see Chasmercm, TrE Trworr of MIo:ropolistic CoMTEtition (2d ed. 1935); Pigod, Econozucs of WeIfare (3d ed. 1929) 267-270,

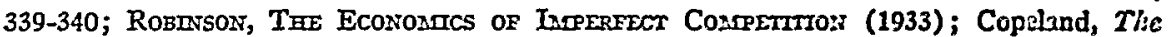
Theory of MLonopolistic Competition (1934) 42 J. Pours. EcoN. 531; Harrod, Doctrines of Imperfect Competition (1934) 48 Q. J. Ecos. 442; Kaldor, Book Review, (1934) 1 Ecoroxaca (N. S.) 335; Lucas, Britislz Moventent for Indiustrial Reconstruction and the Conlrol of Competitive Activity (1935) 49 Q. J. EcoN. 206; Mund, Prices under Compctilion ard Monopoly (1934) 48 Q. J. EcoN. 28S; Nichol, Book Review, 48 Q. J. Eco:. 317; Pribram, Controlled Competition and the Organization of Anerican Industry (1935) 49 Q. J. Econ. 371; Schumpeter, Book Review (1934) 42 J. PoLrr. EcoN. 249; Shove, The Inaperfection of the Market (1933) 43 Econ. J. 113; Sraffa, The Laiss of Returns under Conpctitive Conditions (1926) $36 \mathrm{EcoN}$. J. 535. For an interesting attempt "to throw a fragile bridge acros the wide gulf between the abstractions" of this theoretical foundation for the analysis of monopolistic markets "and the realities which they must finally comprehend" (p. v), cee Buris, The Decrare of Cosmerrtion (1936), which has appeared since this article was written, especially ch. I, II, V, VI, XI, XII; valuable bibliography of the non-theoretical literature at pp. 590-604; and further, Lyon AND Abraxrson, Tre Ecovosmcs of OpEz Price Srstexs (1936) ; Pribratr, Carter Problents (1935); Whitney, Competition tonder Secrel ond Open Prices (1935) 3 Econontetrica 40. 
sumptions on which the theory depends. Thus perfect competition is the price-making mechanism in a market containing a single commodity and many independent buyers and sellers, all perfectly informed as to prices and other trade conditions prevailing in the market. Pure competition, a more limited concept, requires only the premises that there are many sellers and that the product sold is undifferentiated. ${ }^{7}$

Granted the first premise, that there are many sellers, each producing a small share of the supply and thereby little affecting the market, it is clear that for an individual producer, demand is virtually unlimited, and market price is a fixed datum, so that he carries his production forward until the cost of producing one more unit equals the market price. ${ }^{8}$ Such a producer has no pressing interest in market news other than that generally available. A detailed statistical system is of little use to him. The price which a wheat farmer, for example, can command is not altered by the production policy of a neighbor, although concerted action by all producers or a great change in the demand side of the market, which will normally be publicized in the press, will of course alter his conduct by changing his anticipation as to the course of future prices. Under pure competition, to a great extent, the Unseen Hand guides the individual producer; if his price is lower than the market price, the market floods him with demand; if it is above the market price, he cannot sell anything; no isolated change in his output can materially influence the market.

The second premise on which the theory of pure competition depends, that the product be undifferentiated, implies that all sellers can in fact compete with each other, since it is a matter of indifference to buyers from which seller they buy. When, however, identical products are differentiated in the public mind by brand names, advertising, trademarking, and other devices to build up consumer preferences and thus to insulate the producer from competition, it is incorrect to speak of a single competitive market for the commodity. ${ }^{9}$ Competition is reduced by dividing the market into a series of related markets, a price change in one exerting an indirect or deferred influence on prices in the others.

7. For definitions of competition, see CEAMaberLin, op. cit. supra note 6, ch. I-II; Robinson, What is Perfect Competition? (1934) 49 Q. J. Ecos. 104.

8. There are of course several ways, differing mainly in nicety and theoretical uscfulness, in which this concept can be expressed. Cf. Pigov, Economies of Wexpare (3d cd. 1929) 787-812; Marseate, Princtples of Econosucs (8th ed. 1930), Book V., esp. Ch. III, IV, and V; 499; 813-821; 1 Wicksere, Lectures on Political Economy (1934) Ch. 3, esp. 52-68; and note 24 infra.

9. Braithwatte and Dobis, The Distribution of Consumable Goods (1932); Bunns, op. cit. supra note 6, ch. VIII; ChARrBerrors, op. cit. supra note 6 at 204 (Some Arguments in Favor of Trade Mark Infringement and Unfair Trading), Ch. VI-VII; Bralthwaito, Econonic Effects of Advertisement (1928) 38 Ecos. J. 18; Plant, Economic Theory Concerning Patents for Inventions (1934) 1 Economen (N. S.) 30. 
It is familiar learning that under the conditions of pure competition, producers maximize their profits at a price and output which also maximize the social income; under the pressure of consumer preferences conveyed by a price system, resources are allocated to their most productive uses; and the economy is exploiting its opportunities in an optimal manner. ${ }^{10}$ Removal of either or both of the assumptions on which the analysis of pure competition depends results, however, in a conspicuously different state of competition and it is no longer safe even in theory to assume that its social results are salutary. When there are fer sellers of a commodity, the policy of one, either as to price or output, can affect the destiny of the others. Sellers, endowed with a new power to raise market price by refraining from production, must decide at what level of production they will seek to maximize their profits. That decision must be based on data as to the elasticity of the total market demand for their product, that is, the quantitative response of demand to changes in price, and on data as to the total of available supply. Together the sellers can choose a higher price and a lower output, or a lower price and a larger output, depending on their estimates of the elasticity of demand and unit costs at the various levels of production. But, for most industries and under almost any circumstances, actual or theoretical, the output at which their profit will be maximized will be lower, and the price higher, than the putative result in the same market under pure or perfect competition. ${ }^{11}$

By definition the theory of perfect competition is inapplicable to markets dominated by relatively few sellers, which are in part inevitable, granted the scale of many modern industrial operations. Presumably the policy of the anti-trust laws requires that an effort be made to preserve in those markets as much competition as possible, to assure the public as low a price and as large an output as circumstances will permit. The activities of trade associations, which bring together the sellers in such monopolistic markets, must be scrutinized against the background of the economic theory of monopolistic competition.

Some American industries are dominated by monopolies, a few by

10. Pigou, op. cit. supra note $8,129-144,805$.

11. Chandberlin, op. cit. supra note 6,106 , and $\mathrm{Ch}$. III, where the possible caces are taken up separately; while it is not safe to generalize as a matter of theory for the recults in all cases of imperfect competition, since the mistakes of sellers corrected by monopolistic action may be mistakes in the direction of restricting production, the Eeneralization is justified, perhaps, for markets like sugar where the number of producers is fairly large and competition quite vigorous. Cf. PIgov, op. cit. supra note 8 , at 339; Ronnisoin, op. cit. suppra note 6, 143-179, 307-329. For non-theoretical discussions of the effect of monopolization on output, BURNs, op. cit. supra note 6; FETTER, THE MInseunzude of Mrovorour (1931); Robbins, The Great Depression (1934) 59, 71, 136, 143, 182, 189; Wintiet, Trade Associatrons and Industrial Control (1934). 
two large companies, ${ }^{12}$ and perhaps the greater number of large industries, characterized by a heavy concentration of capital (including the control of certain natural resources), are controlled by several firms. ${ }^{13}$ The theory of monopolistic competition applies in diminishing degree as the number of sellers increases, and becomes inappropriate at the point where the industry is composed of so many sellers that no one can exert a material influence on the market. By monopolistic competition, in this paper, we shall mean the mechanism for determining price in a market where there are few sellers.

The anti-trust laws are chiefly concerned with that type of trade association which undertakes activities of which the following are typical: (1) They supply statistical information about prices, output, stocks on hand, and trade conditions to inform their members as to probable trend in prices and the state of the supply in the market, ostensibly to make competition open, intelligent and fair, i.e., to promote rather than to impede competition; (2) they struggle to eliminate discriminations, special discounts and concessions to buyers, on grounds both of ethics and economics; (3) they concertedly fix or eliminate discounts, important contract terms, or such material elements of ultimate price as transportation charges, and even, on occasions, maintain a basing-point system with all-rail delivered prices-all under the euphonious slogan of open prices and non-discrimination; under the same slogan, and to achieve the same end, they boycott distributors or classify them in such a manner as to limit their opportunities for service or trading; and (4) they work toward the improvement and standardization of products, and the extended uses thereof, and they standardize accounting methods and agree upon various terms and conditions applicable in the sale and delivery of their products.

When a trade association becomes so good that it is bad, it may be brought before the Court. There the good and the bad together are described as devices bringing competition into the open, making it fair and effective, preventing discriminatory practices and avoiding useless waste. At this point, eminent economists are invited to the witness stand, cast an occasional precautionary glance at the lifeless form of competition, and recite to the Court the bedtime story of textbook perfect competition. While the prosecution proceeds with the attack upon what it instinctively believes to be monopolistic devices, the defense tries a different case, attuned to the theory of perfect competition. In the excitement of the trial, there is nobody to attempt, with

12. Duopoly. The word is Cournot's, and is used to characterize a market in which there are two sellers. Nichol, A Re-Appraisal of Cournot's Theory of Duopoly Price (1934) $42 \mathrm{~J}$. PoLIr. Econ. 80.

13. Oligopoly. A market in which there are several sellers. Cf. Chasmertin, op. cit. supre note $6,30-53,100$, and literature there discussed. 
academic detachment, an investigation into the economic function and the economic consequences of the several types of trade association activity viewed in their setting of monopolistic competition.

Information: The economic function of information in monopolistic competition is different from its rôle under perfect competition. Under perfect competition it is important for the buyers to know at what prices sellers will sell; and, in a general way, it contributes to the smoothness of adjustments to competition and to forces of the trade cycle if sellers know what demand in the future they can safely anticipate. But under monopolistic competition, where there are few sellers, it is a matter of serious concern for a seller to have detailed bnowledge of what other sellers will do. While monopoly may arise in the absence of complete information, information may be an effective means of attaining monopoly; and the monopolist requires complete knowledge if he is effectively to exploit the opportunity for gain implicit in the fact that there are few sellers. With full information, he can decide more accurately on the price and output policy which will maximize his gain. As his estimates become more accurate, the gap betrreen monopolistic and competitive output becomes greater; sellers exert a more sustained control over the market; and the strain of monopoly upon the economic system as a whole becomes more intense.

The enthusiasm with which a number of trade associations collect statistics, and the amounts of money members are willing to pay for them, are easily intelligible in terms of the theoretical conclusion that detailed knowledge of future trends makes monopolistic competition more effectively monopolistic and less competitive. ${ }^{14}$ This viem of the economic function of statistics in trade association behavior is confirmed by observation of the place which informational services occupy in trade association activity. Where the trade consists of a few sellers, all relatively large in size, the informational services of the trade association are efficient and well developed. But where the trade is scattered and the producing units small, the statistical services decline in importance, and less interest in them is manifested by members. ${ }^{15}$ Where practical conditions preclude effective restraints, ${ }^{10}$ one seldom finds a highly developed statistical service.

14. BunNs, op. cit. supra note $6,26-29,47,55,57-58$; see further Crunomenne; op. cit. supra note 6, 51-53, 106; WHITNEY, op. cit. supra note 11 , at 42, 44-45, 69, 78, 124, and passim.

15. Bunns, op. cit. supra note 6 at 47; F. T. C., Open Price Assocurrons (1929) 307 ;

1 F. T. C., House FuRNISHTIG Industries (1923) 176.

16. Practical observation brings the conviction that relatively few loose agreements in restraint of trade survive the natural influences constantly operating against them. It is suggested that in a period of stress no far-flung industry, with over-capacity and with numerous members of various types and character producing different products or grades of products, can effectively restrain competition for any substantial time. It has been said that 
The Supreme Court has remarked that the exchange of information makes competition more intelligent, an end which it assumed could not be undesirable. ${ }^{17}$ It is manifestly impossible to deny sellers access to each other in a monopolistic market. But to avoid the decrease in output and increase in price characteristic of successful monopoly, their plans for exchange of information must be carefully scrutinized in operation. The benefit which producers may derive from such plans should not be permitted to obscure the dangers to the public interest inherent in them. The first danger is apparent from the foregoing analysis of the economic consequences of a trade association statistical service. The second danger, which neither economist nor lawyer can ignore, is present whenever competitors together operate a mechanism which may be utilized in the more familiar tactics of restraint of competition; as that legendary and hard-headed philosopher, Adam Smith, once remarked, "People of the same trade seldom meet together, even for merriment and diversion, but the conversation ends in a conspiracy against the public, or in some contrivance to raise prices." 18 It may be unfair to prejudge the existence of this illegality, particularly where business men are acting under careful advice. But to assume that these dangers are non-existent is to follow a rule of "reason" which ignores the most elementary experience with business groups.

Discrimination: Trade association activities aimed at suppressing discrimination involve a similar fallacy in applying conclusions based on the premises of perfect competition to a situation requiring analysis in terms of the theory of monopolistic competition. Discrimination has long been unfavorably regarded by business men and the public: by business men because as a class they disapprove of any competition which brings price reductions; and by the public since it has seen discriminatory devices used not only to obtain business, but also to bankrupt competitors and strengthen monopolies. It has been used as a major

"nature enforces the anti-trust statutes in the bituminous industry." [George Otis Smith as quoted in Hasmion and Wriget, The Case of Bituminous Coar (1925) 42.] This is probably true to an unsuspected extent in many other industries. The practical difficultics working against loose agreements in restraint of trade are indicated by the following list of factors, a preponderance of which must be present to an efficient degree if the breakdown is to be avoided: (1) a standardized commodity, economically as well as physically; (2) tho working control of the entire industry; (3) this control lodged in the hands of a small number of powerful member companies efficiently organized; (4) a minimum of over-capacity; (5) a natural or legally required limitation of production; (6) a minimum of danger from inter-industrial competition; (7) cooperation of distributors; (8) constant surveillance by efficient trade association executives and staff; (9) thorough exchange of information; (10) general cooperative attitude; (11) intelligent self-interest and self-restraint; (12) frequent meetings.

17. Notes 36, 37 infra.

18. I Adam Samth, The Wealth of Nations (6th ed. 1793) 134. 
weapon by the monopolist who is best equipped to carry on an unfairly discriminatory system. Professor Edwin R. A. Seligman, testifying for the Sugar Institute, on direct examination, formulated the popular dislike of discriminations by remarking: ${ }^{10}$

"The nearer we get to the conditions of open competition, the nearer we get to the theory of economic competition with general public beneficial results, as is understood by economists. It follows that the further away we get from secret rebates, preferential concessions and the like, the nearer we get to this policy and system of open competition."

The difficulty with the argument is simple. It is clear that elimination of discriminatory practices forces the market closer to perfect competition if there are many sellers, one of whom is attempting to monopolize the market. But for a market in which monopolistic competition prevails, the alternative to discriminatory monopoly is not perfect competition, but more perfect monopoly. A system of rebates, concessions and other discriminations among sellers would probably result in the sale of more of the commodity than would be sold if the market were a oneprice monopoly, ${ }^{20}$ and to sell that output, moreover, at an average price, lower, potentially at least, than the simple monopoly price. ${ }^{21}$ The cases of discrimination which actually threaten the existence of any competition, concededly undesirable, and illegal under the Clayton Act, should not conceal the fact that on the whole the public may get more for less from a discriminatory monopoly than from a monopoly unresponsive to price pressure.

The economist for the defense tended to overlook the fact that in the actual case before the Court, all differences in price had been eliminated, whether or not those differences were essential to equitable dealing under the varying circumstances of different transactions. Elsewhere Dr. Seligman had written "The very essence of usual business practice is this system of different prices to different customers." ${ }^{\text {.22 }}$ But he testified in the Sugar Institute case that adequate price pressure would be exerted by buyers as a class. This contention ignored the utter lack of organiza-

19. Record 1133, Sugar Institute, Inc. v. United States, 56 S. Ct. 629 (1936).

20. Pigou, op. cit. supra note 8 at 275-290, esp. 286-287; Rondisoni, op. cit. sugra note 6 at 179-208, esp. 206.

21. The solution of this problem is theoretically indeterminate, depending for each case on the relations between the elasticities of demand for the commodity in different marliets and the cost of producing various outputs of it. For a clear analysis, cf. Ronsison, op. cit. supra note 6 at 179-187. There are cases, as the experience of the sugar market indicates, where discrimination by the monopolist probably does result in a lower average price than under a regime of perfect monopoly [see MLARSHALI, IndUSTRE ARD TRADE (1927) 415, 416] exactly as competition among monopolistic competitors lowers price and raises output, 1 WrCksert, op. cit. supra note 8 at 97.

22. Seligaran, Prnictiles of Economics (1914) 149-150. 
tion among the numerous, far-flung purchasers, and the fact that each purchaser was left individually to cast his small pebble against the stone wall of uniformity maintained by the collective action of the limited group of powerful sellers. It is difficult to imagine how a market so organized could be classified as an example of perfect competition.

Elimination of discrimination was defended not only as a contribution to the perfection of competition, but further as a step against unfair competition. Unfairness of competitive method is a question on which discussion has been prolific, but barren. It is plain that what business men regard as unfair will often appeal to the economist as wholesome and competitive. Secret rebates and hidden concessions have a sinister sound; but after all they are frequently the response of sellers to a market in which the general price is artificially stabilized, or the supply of goods artificially restricted. Restriction schemes have usually been destroyed by forces which they themselves set up, and the history of the sugar industry is no exception to the general experience. ${ }^{23}$ There seems to be no reason of policy for allowing sellers thus caught in their own trap to liquidate the failure of their grandiose plans of raising price by restricting supply at the expense of the community.

Fixing Elements of Price: Economic objections to the third group of trade association practices, including substantial restraints of trade such as limitations on discounts and transportation charges, and boycotting of distributors who fail to comply with trade association rules, involve simple bias in favor of freedom of competition. ${ }^{24}$ The interference with price competition is obvious, and its effect in reducing the area within which competition is effective quite clear. Dr. Seligman testified on direct examination in the Sugar Institute case: $:^{25}$

"When $\mathrm{T}$ say that uniformity of price is compatible with conditions of free or economic competition I do not imply that such free or economic competition would be restricted or rendered imperfect because the refiners refrained from the practices condemned in the Code."

Lurking in this negative statement were implications in conflict with basic economic theory, or based on a most artificial assumption of facts. The Sugar Institute Code, for example, fixed transportation charges,

.23. See infra p. 1358 for history of industry; as to freight rate restraints sec opinion of the District Court, R. 128; outside competition, R. 223, note 25. For more general treatment of the problems of the industry, see Rowe, MARKETs AND MEN (1936), a thorough study; Rowe, Studies in the Artificial Control of Raw Material Supplics: Sugar (1930) 31 London \& Cambridge Econ. Service.

24. See Watkins, Industrial Combinations and Public Policx (1927) 98. Sea also Watkins, The Economic Philosophy of the Anti-trist Laws (1930) 147 (No. 236) AnNars 12, 21, 24 ; Bye, Principles of Econonics (1932) 56-58; Clark, Essentiats of Economic Theory (1907) 559; Fetter, Masquerade of Monopoly (1931) 261; cf. Casser, 'TuE: THEORY OF SOCIAL ECONOMY (1932) 118.

25. Record 1127. 
eliminated quantity discounts, and called for the boycotting of distributors, and required the seller to give the same price to all buyers. On cross examination Dr. Seligman testified: ${ }^{26}$

"The only requirement of the theory of free competition is that the conditions under which the commodity comes into the market and the conditions under which the sale is made should be free and open ...

"It is requisite or desirable that the freight charges to each one should be known to each but not fixed by anyone.

"True competition does not render either necessary or desirable sugquestions from a trade association to the sellers as to what prices or freight rates the sellers should charge. That is very undesirable.

"True competition does not require that all customers in a given market shall be charged the same prices and terms regardless of difierences in other substantial factors, such as the quantity purchased, the method of taling delivery, credit standing and others."

There the economist dealt with the actual case before the Court, and upon that case, he clung closely to the controlling economic theory that trade should be free from substantial restraints.

Standardization: Finally, there is a fourth group of trade association activities lumped together somewhat loosely as standardization practices which of themselves involve no substantial restraint. Competition is more effective with an undifferentiated product and with the elimination of meaningless distinctions between grades and brands. Customer preferences tend to deflect competition. Some standardization rules may introduce desirable economies of marketing. There are no theoretical objections to most standardization practices sponsored by trade associations until the slogan is used to mask rules directly interfering with the market freedom which it is the policy of the law to sponsor..$^{2 z}$

The foregoing discussion of typical trade association activities does not pretend to do more than sample the field. The classification, particularly of the group labelled standardization practices, is one of convenience, and necessarily arbitrary. In that field of trade association work, and in others, a measure of self regulation of the market may be conducive to economical trading. Even the economist doesn't object to all rules of the market, whether sponsored by a trade association or by a more detached body. Medieval fairs are generally classified as almost

26. Record 1137-1138.

27. In the Sugar Institute case this feature caused certain "standardization" rules of the Institute to be condemned. District Court opinion, R. 195-19s; and cf. R. 233 et seq. It should be noted that the very existence of actual or assumed difierences in product may narrow the monopolistic competition in the resulting market. Cf. "The fact that because sugar is a standardized commodity, there is a strong tendency to uniformity of price, malies it the more important that such opportunities as may exist for fair competition should not be impaired." The Chief Justice in Sugar Institute, Inc. v. United States, $56 \mathrm{~S}$. Ct. 629, 643 (1936). 
perfectly competitive and they were protected by their own rules and by the statutes against forestalling, engrossing and regrating. ${ }^{28}$ The idea that competition should not be wholly unregulated by the competitors themselves is implicit in such governmental restrictions as Section 2 of the Clayton Act and Section 5 of the Federal Trade Commission Act. Under the law as outlined in the Sugar Institute case, and in accordance with the underlying policy of these statutes, trade associations are still free to demonstrate a capacity for bringing competition to a higher degree of fairness and efficiency..$^{29}$ Trade associations can and do perform socially useful functions; their activities vary widely; and there is no basis for a blanket condemnation of them as illegal under the trust laws. Some of their practices tend to improve competition when not misapplied. But, in dealing with the particular type of association which undertakes most or all of the activities discussed above, it should be recalled that the public is facing a monopolistic market with great resources for monopolistic action. The associations are frequently prepared to rationalize an extension of the field of permissible activities into the field of substantial restraints. This temptation and its dangers to the competitive system are typically reflected in the position of the amici, representing several trade associations in the Sugar Institute case. They asserted that the practices condemned by the Institute were "secondary and incidental" and did not affect "the fundamentals of the competitive process" nor "go to the very heart of this law" but were "at best on the periphery of the scope of the law." They also contended that the combination had in fact produced little effect. At the same time they described the problem actually facing industry as a basic failure of the competitive system itself: $:^{30}$

"The competitive process, functioning normally, is dual in its natureactive competition among sellers in disposing of their product-active competition among buyers in securing their requirements. While both sides of the competitive process are active, there is a balance which is productive of a competitive price, fair to both buyer and seller. Actual or potential scarcity on the one hand, or actual or potential surplus on the other, immediately destroys this balance...

"Both situations tend to create prices which bear no reasonable relation to the cost of production. They are not the fair competitive price of balanced competition ...

"If such conditions are due to merely temporary causes, they are rapidly self-corrective. But as the record of the coal industry before this Court showed, and as the records of the cotton textile, lumber and many other

28. Jones, Historical Development of the Law of Business Competition (1926) 36 YALE L. J. 207; Handler, loc. cit. supra note 1; Oliphant, Trade Associations and the Law (1926) 26 COL. L. REv. 381.

29. Cf. Watkins, supra note 24.

30. Brief of Amici Curiae, 16-17. 
industries would show, the lack of balance in the competitive process does not cure itself readily by the bankruptcy route."

Does this not amount to a suggestion that competition will not function in the public interest, and that industry should be able to take a firm hold on the balance wheel of the competitive system? And does not the diagnosis of the basic ill made by the amici invite the conclusion that the rules of the combination are in fact designed to effect a change in the basic features of a competitive economy?

The economic consequences of monopolistic trading when organized by small powerful groups of sellers is to heighten the sellers' collective control over supply and over price and the key elements in price. Viewing these trade associations in such a perspective, as agencies for making monopolistic competition between relatively few sellers more effectively monopolistic, one comes to the problem, of legal control with a definite technique for analyzing their economic implications.

The Cases Dealing with Loose Combinations of Competitors. The technique of the judicial opinions on trade-association activities has hardly paralleled economic theory with any notable precision. But a brief reference to the leading decisions, exhaustively discussed elsewhere, ${ }^{31}$ indicates that the results reached by the Court in a majority of cases are not inconsistent with an economic analysis of the trade association problem, and that the tentative drift of the anti-trust laws, at least as to trade associations, is a consistent one roughly in this direction..$^{32}$ It may be that the cases map a path of permissible cooperation among business competitors with greater certainty than is generally assumed.33

In the cases dealing with loose combinations, the Court has assumed that underlying the statute is the proposition that the basic elements of the competitive system should be preserved. Upon this assumption the Court has picked out a field of permissible conduct which it felt might tend to bring competition into the open and make it more intelligent and efficient, and fairer. No agreement shown to be a substantial impediment to free trade has been approved, with the possible exception of the agreement in the Cement case, while at the same time the Court has tended to approve restraints of a minor character where their dominant purpose and effect were to improve the efficacy of the competitive system. $^{34}$

31. Jones, loc. cit. supra note $2 \mathrm{~s}$; Handler, loc. cit. supro note 1; Oliphant, loc. cit. suspra note 28.

32. The writer does not feel that this guess applies in the monopoly enses. See note 43 infra.

33. Most of its uncertainty has been lugged into the law by the Rule of Reason. Cf. references in notes 1 and 4 supra.

34. The Court has held that price fixing is illegal, however rezsonable the prices. United States v. Trenton Potteries Co., 273 U. S. 392 (1927). This holding does not 
In the Hardwood and Linseed Oil cases, ${ }^{35}$ the Court dealt with plans ostensibly designed to bring about "open, well-informed" competition. The reporting of prices and the exchange of statistical information were involved in each case. The Court felt that the purpose and effect of

indicate that the Court has declined to apply the rule of reason to price fixing. It cannot be assumed that it is "unreasonably" inflexible to conclude that the elimination from competition of its most important element is necessarily contrary to the statute. Accurately speaking, there is no price fixing where the combination cannot establish the market price. See Appalachian Coals, Inc. v. United States, 288 U. S. 344 (1933). It would seem that an agreement of a controlling group actually fixing a substantial element of price should bo condemned as unreasonable, but that the similar fixing of unsubstantial elements may be found reasonable in the light of circumstance. Cf. Jaffe and Tobriner, The Legality of Price-Fixing Agreements (1932) 45 HaRv. L. Rev. 1164. Even for strong business reasons the Court generally will not permit boycotts or the domination of the business of a second group. Eastern States Retail Lmbr. Dealers Ass'n v. United States, 234 U. S. 600 (1914); United States v. Trans-Missouri Freight Ass'n, 166 U. S. 290, 323-324 (1897); United States v. Addyston Pipe \& Steel Co., 175 U. S. 211, 244-245 (1899); Montague v. Lowry, 193 U. S. 38 (1904); Binderup v. Pathe Exchange, 263 U. S. 291,312 (1923); United States v. First National Pictures, Inc., 282 U. S. 44 (1930); cf. Paramount Famous Lasky Corp. v. United States, 282 U. S. 30 (1930); Handere, SyMpostum on trre Federuat, ANTI-Trust Laws (1931) 63; but see United States v. American Livestock Co., 279 U. S. 435 (1929). A combination may eliminate a type of trading which in fact impedes competition and may drive it on to the floor of an active competitive exchange; and it seems that a combination may impose restrictions designed to prevent frauds and indefensible waste. Chicago Board of Trade v. United States, 246 U. S. 231 (1918); Cement Manufacturers Ass'n v. United States, 268 U. S. 588 (1925); Appalachian Coals, Inc. v. United States, 288 U. S. 344 (1933); Swift \& Co. v. United States, 196 U. S. 375, 393-395 (1905). The decree considered by Mr. Justice Holmes in the Swift case forbade agreements curtalling quantity of meats shipped to markets, establishing of credit rules, or imposing of cartage charges, where the effect would be to restrict competition. The sweeping injunction, however, excluded agreements on "cartage and delivery, and other incidents connected with local sales ... not contemplated to have any effect upon competition," and agreements fixing credit rules calculated solely to protect against dishonest dealers, and agreements curtailing shipments in order to prevent the over-accumulation of perishablo meats in local markets. Cf. the early English statutes against forestalling and engrossing, designed to promote competition at the medieval fairs, discussed in Jones, Historical DCvelopment of the Law of Business Competition (1926) 35 YALE L. J. 905. On restriction of production, see American Column \& Lmbr. Co. v. United States, 257 U. S. 377 (1921); Standard Sanitary Mfg. Co. v. United States, 226 U. S. 20, 38 (1912); cf. Coronado Coal Co. v. United Mine Workers, 268 U. S. 295, 310 (1925); but see, as to incidental regulation of production to avoid waste and to assist in adjusting labor and industry to technological change, National Ass'n. of Window Glass Mfg'rs v. United States, 263 U. S. 403 (1923); as to price fixing, United States v. Trans-Missouri Freight Ass'n, 166 U. S. 290 (1897); regarding division of territory, see United States v. Addyston Pipe \& Steel Co., 85 Fed. 271 (C. C. A. 6th, 1898), aff'd 175 U. S. 211 (1899); as to combinations involving patents, sce Standard Oil Co. (Ind.) v. United States, 283 U. S. 163 (1931); cf. Standard Sanitary Mrg. Co. v. United States, 226 U. S. 20 (1912); on market corner, see United States v. Patten, 226 U. S. 525 (1913); on restricting traffic, see United States v. Pacific \& Arctic Ry. \& Navigation Co., 228 U. S. 87 (1913).

35. American Column \& Lmbr. Co. v. United States, 257 U. S. 377 (1921); United States v. American Linseed Oil Co., 262 U. S. 371 (1923). 
the plans were illegally to suppress competition. In its decrees the Court made no effort to save any commendable feature of the schemes. The dissents in the Hardwood case, however, were significant. Mr. Justice Holmes, noting that the basic question involved merely the exchange of information, stated: ${ }^{36}$

"I should have thought that the ideal of commerce was an intelligent interchange made with full knowledge of the facts as a basis for a forecast of the future on both sides."

Mr. Justice Brandeis emphasized the combination's lack of control (onethird of capacity was involved), the far-flung and disorganized nature of the industry, with its numerous members, and expressed the fear that, without efforts to rationalize competition, its members would be invited into the field of consolidation and the smaller concerns eliminated.

The majority stressed the high-pressure methods of the association officers and concluded that the plan for the exchange of detailed information was being utilized for control of price and production. It is probable, however, that the great war and foul weather, respectively increasing demand and decreasing production, were largely responsible for the increase in price, which made the association appear profitable to its members and illegal to the Court.

The Linseed Oil case involved the exchange of price lists and detailed statistical information between the members, comprising a large portion of the industry. Production was restricted by a limited supply of raw materials. The plan was designed to render competition substantially imperfect. The buyers were numerous, weak and unorganized. The sellers were fewer, stronger and organized. The association worked to keep the prices in line. Under these circumstances, information as to trade conditions was concealed from the trade. Such an unbalanced competition was contrary to the statute and the theory of competition underlying it.

The dissents in the Hardwood case guided the majority opinion in the Maple Flooring case, where the Court held: $:^{37}$

"We decide only that trade associations or combinations of persons or corporations which openly and fairly gather and disseminate information as to the cost of their product, the volume of production, the actual price which the produce has brought in past transactions, stocks of merchandise on hand, approximate cost of transportation from the principal point of shipment to the points of consumption, as did these defendents, and who, as they did, meet and discuss such information and statistics without however reaching or attempting to reach any agreement or any concerted action with respect to prices or production or restraining competition, do not thereby engage in unlawful restraint of commerce."

36. American Column \& Lmbr. Co. v. United States, 257 U. S. 377, 412 (1921).

37. Maple Flooring Mfg'rs Ass'n. v. United States, 268 U. S. 563, 586 (1925). 
Here was something upon which industry might rely, but implicit in the careful wording of the decision was a warning that industry should not use its new freedom in such a way as to impede competition. Future price reporting was not involved, and no agreement restricting competition was before the Court. The Maple Flooring decision was reached only after extended consideration by the Court, after reargument, and over the dissent of three justices. Solicitous in tone, in fact it impaled the Hardrood decision.

Government counsel in the course of the presentation had rested the case upon the "necessary effect" of the trade association plan. Proof of actual operations went by the board. ${ }^{38}$.The opinion was strongly influenced by the stress laid by the defense economists on the gathering and dissemination, in the widest possible manner, of information with respect to production and distribution, cost and prices in actual sales and of market conditions, supported on the ground that this information would tend to produce a free and open market among both buyers and sellers. The association was composed of numerous members, and there was ample outside competition. No adverse effect on prices was established, and the prices of non-members were in fact higher than those of members. There was in fact no substantial uniformity of prices. Prices received in past transactions only were reported; and all statistical information was published to the trade generally. The association functioning in this manner was offensive to neither the legal nor the economic theory of competition.

The Cement case $^{39}$ is not easily reconciled with the preservation of competition. While the exchange of information on specific job contracts, in order to expose and prevent frauds of purchasers, is adequately justified, the approval of the broad scheme for the exchange of information requires more careful scrutiny. It may be suggested that the majority of the Supreme Court, over-eager to establish what it considered a liberal doctrine of "open and intelligent competition," as propounded by the combination's economists in the Maple Flooring case, overlooked the distinguishing features of the Cement Association's activities. Unnoticed were the District Court's critical analyses of the highly detailed statistical system, the control of defendants throughout an important market area, their cooperation with other regional associations in the industry, the concealment of pertinent information from the purchasing

38. It may well be assumed that counsel had sound reason for presenting the caso in the abstract, in view of the positions theretofore maintained by the Government in the leading trade association cases and the apparent prospect that the consideration of the plan, without reference to its effect in actual operation, would lead to the Court's condemning it and thus further restricting trade association activities and limiting the embarrassments in the proof of restraint.

39. Cement Mfg'rs Ass'n. v. United States, 268 U. S. 588 (1925). 
side of the market, and their supplementary devices. The Supreme Court was not critical of the restriction of production and the unnatural uniformity of prices which the trial court attributed to the system. Reanalysis of the facts of the case in the light of the theory of monopolistic competition would have invited a different result. It should be noted, however, that the Hardwood and Linseed Oil cases were not expressly overruled.

The upshot of these cases seems to be that statistical services are probably legal if the court can be persuaded, which is apparently not now a difficult job, that they substitute a fair knowledge of market conditions for ignorance; but a system ostensibly designed to produce open competition, by the reporting of prices and information as to supply and demand, may not legally be designed or utilized to suppress price competition or to limit production. ${ }^{40}$ It remains to be seen how realistically the courts will respond to a more critical analysis of trade association informational activities.

In the Appalachian Coals case practical considerations were overwhelming. The competitive system had failed in a unique manner in the bituminous coal industry. Huge capital investments were fixed in localities where large populations were dependent solely upon the industry's operations. Fluidity as to both capital and labor was at a minimum in that industry. A natural inelasticity of demand effectively blocked an increase, while technological changes in this and other industries continue to decrease the ordinary demand. The burden of a large overcapacity was exaggerated by the necessity of producing sizes of coal for which there was no demand, in the course of mining that which was required. The group had been brought to its knees by aggressive competition in both the producing and the distributing phases of the industry. ${ }^{41}$

The Court emphasized the "economic conditions peculiar to the coal industry" and the facts of this particular case, and considered "the probable consequences of carrying out" the sales agency plan of the defendants "in relation to market prices and other matters affecting the public interest."12 It concluded that the plan would not give the association, which constituted a majority of the producers in a given pro-

40. American Column \& Lmbr. Co. v. United States; United States v. American Linesed Oil Co., both supra note 35.

41. Cf. Haxmiton and Wright, The Case of Brtuamous Cons (1925) c. IV and c. IX. The problem of the industry is succinctly outlined in Handler, sufra note 1 , at 25 ; sce Comment (1932) 42 YALE L. J. 233 for a study of the relation of the Sherman Act to the bituminous coal industry prior to the Appalachian Coals decision; and Comment (1935) 45 Yate L. J. 293 for a study of the industry in connection with the Guffey Coal Bil.

42. Appalachian Coals, Inc. v. United States, 2SS U. S. 344, 361 (1933). 
ducing area, control in any consuming market, since there would always be effective competition from other producers in each market, and since the group inevitably would deal with powerful and well-organized buyers. Although the Supreme Court approved the finding of the court below, that the agency might "affect" prices and raise them to a higher level, at the same time it emphasized the finding that the group was unable to fix prices in any market. It appears obvious that the Court entertained the opinion that the agency, although it might improve the efficiency in production and distribution of coal and in some measure alleviate the competitive conditions, could not effect any substantial restraint. Perhaps the Court was moved in this direction by the same fear of merger and consolidation which had found expression before. ${ }^{43}$

The Appalachian Coals case has been interpreted as indicating a tendency of the Court to judge the activities of trade associations by the same criteria which have been applied to mergers.44 Such a reversal of direction is hardly to be inferred from a minor shift of emphasis in a particular case. It should be noted, in evaluating the decision, that the Court dealt with the plan in the abstract, that it believed no substantial restraint probable, and that it specifically retained jurisdiction in order that proof of substantial restraint in the course of actual operations might be brought before it.

The absence of general monopolistic power is not decisive of legality in a trade association case. The question of market control, however, is of importance in determining the substantiality of the restraint. Degree of control has been repeatedly emphasized in the prevailing and dissenting opinions of the trade association cases. However, these cases do not establish that any given degree of control is necessarily decisive. The ultimate test of legality is the actual or probable effect of the

43. Concentration of wealth and industry control in single corporations has driven on apace while the monopoly section of the Sherman Law has been devitalized by such decisions as United States v. United Shoe Machinery Co., 247 U. S. 32 (1918); United States v. United States Steel Corp., 251 U. S. 417 (1920); United States v. International Harvester Co., 274 U. S. 693 (1927); cf. dissenting opinion of Mr. Justice Brandels in American Column \& Lumber Co. v. United States, 257 U. S. 377, 418-419 (1921); Jafie and Tobriner, loc. cit. supra note 34; Handler, Industrial Mergers and the Anti-lrist Laws (1932) 32 Col. L. Rev. 179. Moulton, Incone and Econonac Progress (1936) 31: "On the other hand, the price of steel rails and plates, farm tractors, . . . and men's shoes either increased or remained practically stationary. In such lines as this latter group it is apparent that gains in efficiency resulting from technological progress were not manifesting themselves in price reductions to consumers." At the same time, $\$ 7$ of the Clayton Act, aimed at secret holding companies, forbidding acquisition of stock in a competitor, was by administrative fiat construed to permit the acquisition of stock of a competitor, where the company receiving the stock transferred all of its assets to the competitor and immediately faded out, distributing the stock, its only remaining asset, to its own shareholders. Merger of Bethlehem Steel Corp. \& Lackawanna Steel Co., 33 Ops. Att'y Gen. 225 (1922).

44. See Comments (1933) 28 ILl. L. Rev. 265; (1933) 31 Mrcr. L. REv. 837. 
restraint in any one market. ${ }^{45}$ The breadth of the Court's inquiry in these cases was made clear in the Appalachian case itself, where the Court stated that "the question of the application of the statute is one of intent and effect" and emphasized that "there is no intent or power to fix prices," and that it did not appear that "defendants' plan will have an injurious effect upon competition in these markets." 1 is is not unlikely, moreover, that the Court will condemn the elimination of price competition among a limited number of sellers substantially affecting prices in any market, even though they may lack actual control of such market. ${ }^{47}$ It seems that an agreement among a few sellers for the single dominant purpose of eliminating price competition between them may be condemned even though the direct effect of the combination on market prices is small. In case such a group is composed of weak sellers, the question might turn on such factors as the existence of a few dominant, aggressive competitors in the same market and the presence there of powerful, well-organized buyers tending to deal unfairly with the weak sellers.

It is apparent that the Appalachian case falls short of approving for loose combinations such control of production, sales and distribution as have escaped the law through merger, or such effect upon price competition as may be accomplished through merger.

In the Sugar Institute case the Supreme Court observed that: ${ }^{45}$

".... a fact of outstanding importance is the relative position of defendants in the sugar industry. We have noted that the fifteen refiners, represented in the Institute, refine practically all the imported raw sugar processed in this country. They supply from 70 to 80 per cent. of the sugar consumed. Their refineries are in the East, South and West, and their agreements and concerted action have a direct effect upon the entire sugar trade. While their product competes with beet sugar and 'ofishore' sugar, the maintenance of fair competition between the defendants themselves in the sale of domestic refined sugar is manifestly of serious public concern."

In view of the cooperative attitude prevailing throughout the sugar industry, the sentence last quoted was hardly necessary to the decision. But the assumption by the Court that outside competition existed carries real significance. For here a combination was held illegal despite the assumption that twenty-five per cent of the industry was in active competition with it. This result may be compared to the Harvester case, where the company was legal although it owned the major portion of the industry and actually established the price which the competitors

45. United States v. Live Poultry Dealers Ass'n., 4 F. (2d) 840 (C. C. A. 2nd, 1924), cited with approval in United States v. Trenton Potteries Co., 273 U. S. 392, 401 (1927).

46. Appalachian Coals, Inc. v. United States, 2ss U. S. 344, 361, 375 (1933).

47. Cf. Jaffe and Tobriner, supra note 34 at 175-179; Handler, supra note 1 at 25.

48. $56 \mathrm{~S}$. Ct. 629, at 643 (1936). 
saw "proper in the exercise of their own judgment to follow" - this despite the fact that a few years before the Court had condemned a loose combination of companies representing only one-third of the hardwood industry for carrying out a cooperative plan to ease price competition. Today, we are reminded that, although a small percentage of the steel and harvester industries, playing "follow-the-leader," will save the dominant company from condemnation, the absence of price fixing itself and the existence of twenty-five percent outside competition in the sugar industry will not save a loose combination of sugar refiners. It seems safe to assume that the trade association cases will not follow the merger cases, and of course they should not. ${ }^{50}$ The language of the Appalackian case, apparently minimizing the distinction between mergers and loose combinations, may indicate a shift of the merger cases in the direction in the loose association cases: "The question in either case is whether there is an unreasonable restraint of trade or an attempt to monopolize."

\section{The Sugar Institute Case}

The Background. The historical background of the Sugar Institute case illustrates most of the issues, both of law and of economics, which are involved in the social problem of controlling trade association activities. Monopoly early took root in the sugar industry of the United States. Competition prior to 1887 had eliminated thirty-six refineries, leaving only twenty-six refineries operated by twenty-three companies. At that time seventeen companies, controlling twenty refineries and seventy-eight percent of production, entered into a trust agreement. A week before the enactment of the Sherman Law, on motion of the State of New York, the Court of Appeals of that state held that the charter of the North River Sugar Refining Company should be forfeited, because the corporation had entered into a partnership agreement, thus acting beyond its charter powers. The court noted that: ${ }^{51}$

"At the command of that master, it has ceased to refine sugar, and, without any doubt, for the purpose of so far lessening the market supply as to prevent what is termed 'overproduction." "

The monopoly was not destroyed, however. The trust shares were already transferred to the American Sugar Refining Company, and some weeks prior to the decision in the North River case, American had obtained control of the companies producing ninety-eight percent of the nation's supply of sugar. In 1894 this combination was held by the Supreme Court of the United States ${ }^{52}$ to be a monopoly in the manu-

49. United States v. International Harvester Co., 274 U. S. 693, 708 (1927).

50. It is suggested that over-emphasis on the monopoly section (\$2) in the merger cases has tended to divert attention from the question whether there was a combination in restraint of trade in violation of $\$ 1$.

51. People v. North River Sugar Refining Co., 121 N. Y. 582, 623, 24 N. E. 834, 840 (1890).

52. United States v. Knight Co., 156 U. S. 1 (1894), a case long treated as overruled, 
facture of a necessary of life-but not, at least as described in the bill of complaint, a monopoly in interstate commerce in violation of the Sherman Act.

But economic forces were more powerful than the legal. The holding company stock was heavily watered; the plants were numerous and not wholly efficient; promoters' profits were great; and prices were high. Heavy dividends followed. Such a situation invited competition. When it came, the monopoly opposed it by fair means and foul. The company's position was so vulnerable, however, that by 1910 it controlled little more than half the production. At this point the Government, at long last, filed a bill in equity to dissolve the holding company as a monopoly of commerce in sugar. ${ }^{53}$ Only in 1922, however, was a consent decree entered which left the American with direct control of $25 \%$ of the nation's production and a $25 \%$ stock interest in the National Sugar Refining Co., the next largest company, a $31 \%$ interest in the Great Western Sugar Co., the largest beet sugar producer and $34 \%$ of the capital stock of the Michigan Sugar Co., another beet sugar concern.

War, and the immediate post-war scarcity, brought government regulation and high prices. With a return to normal conditions the market broke. The related National was of less concern than a robust young company, The California \& Hawaiian Sugar Refining Co., Ltd., which appeared out of the West, controlled and impelled by the vast sugar cane plantations of Hawaii, and began to make substantial inroads on the market. A dozen minor companies were in the field, and the sugar monopoly had become a oligopoly. American's production was decreasing. Both American and National were delivering a large amount of sugar at concession prices. Their profits were diminishing. These companies took the lead in forming the Sugar Institute.

In 1927 the fifteen defendant refiners produced virtually all of the refined cane sugar and three-fourths of all sugars consumed in this country. In the Institute's operations, beginning early in 1928, they had the cooperation of the entire sugar industry. Generally speaking, defendants themselves dominated the markets. Refined cane sugar was thoroughly standardized; competition was a matter of price. Announced basic prices were generally uniform; but secret concessions were rampant, and in a variety of ways and in irregular and substantial amounts were given on at least thirty percent of all sugars sold. An over-capacity of at least fifty percent had existed since the war. ${ }^{\sigma / 4}$ Pertinent statistical

although this may not be a propitious time to assert that its doctrine is dead. Cf. Carter v. Carter Coal Co. -U. S.- (Miay 1S, 1936).

53. United States v. American Sugar Refining Co. et al., filed November 28, 1910 S. D. N. Y., consent decree entered May 9, 1922 and modified February 25, 1927.

54. Based upon normal demand and ordinary working day, without allowance for peals or for extra-hour production. 
information was lacking. The raw sugar market was highly speculative; over-production was general; dumping was taking place; the slimness campaign was on and consumption was decreasing; discriminations in price were frequent and disturbing; and profits were small. In a period of general prosperity competition was extreme, and conditions in the sugar industry were discouraging to the producers.

Summary of Institute Activities. In the midst of these conditions, and to an extent under the aegis of the Department of Justice, the defendants, at the beginning of 1928, organized the Sugar Institute. Their stated purposes were to require open prices in the market for sugar and to eliminate discrimination and other competitive practices which they considered unfair and wasteful. The trial court found, however, that the Institute's dominant purposes were the maintenance of a uniform and enhanced price structure and the elimination of secret concessions. Other important purposes included the publication of binding future prices, the elimination of discriminations, the exchange of statistical information, the elimination of waste, and an increase of consumption. The Institute issued a manual of approved trade conduct, called a Code of Ethics, built in terms around the principles of "open prices and nondiscrimination;" an extensive body of "interpretations" was superimposed on this Code, containing a number of restraining devices. The Code and its interpretation contributed invariably to the effective realization of the Sugar Institute's dominant purposes and thus made the sugar market more efficiently monopolistic in its operation.

That prices were to be "open" required that they be announced through the Institute, and through normal channels, to competitors and to the trade in advance of sale. Changes in important terms were publicized in like manner. No deviations were permitted, and few, if any, occurred. All discriminations were forbidden, and all customers of each refiner got their sugar at the same price regardless of the varying circumstances of the particular transactions.

The Institute collected, and disseminated in summary form, various statistics having to do with the state of the supply and the demand. A portion of these did not go to the purchasing trade. The Institute eliminated all discounts, including quantity discounts. It eliminated long-term contracts-those calling for delivery beyond the usual thirtyday period. Tolling contracts, whereby the refiner agreed to refine raws belonging to the purchaser, were stricken down. The Institute equalized freight rates, and for a time maintained all-rail delivered prices, refusing to sell f.o.b. base points when requested. It placed various restrictions on transportation facilities and their use by purchasers, and impaired their right to use the transiting and diverting privileges. The Institute forbade allowances to customers for the return of used bags. 
It fixed various uniform terms. The combination controlled the sales of damaged sugar and of stocks frozen in a place which did not afford a ready market. It eliminated a great number of consignment points, where the refiners had maintained storage stocks for local deliveries. It boycotted distributors who endeavored to continue to serve in more than one capacity, as purchaser, broker, warehouseman, etc. Packing of sugar under customers' private brands was forbidden by the Institute. It forced all brokers to adopt the Institute's Code. The group fixed brokerage rates, and required all warehousemen to sign a uniform agreement. All off-shore refiners (non-members) were brought under the influence of the Code, and the Institute cooperated in the organization and operation of the Domestic Sugar Bureau, a similar association for the beet sugar industry. The Institute maintained a group of investigators who looked into records of refiners, - brokers, warehousemen, etc. to discover violations of the plan.

It did all of these things for the professed purposes of producing an open, well-informed, fair and non-discriminatory competition. An enhanced and uniform price of sugar, and a market dominated by the refiners, were the outstanding results.

The Scope of the Issues in the Sugar Institute Case. The structure of argument in the case was simple. The defense thought that the underlying issues were: 1 . The validity of defendants' purposes and their good faith; 2. (a) the nature and legality of "open prices and nondiscrimination," (b) the effect of defendant's plan on prices and profits, (c) the necessity, reasonableness and legality of the supplementary agreements adopted to make effective their basic policies. The Government complained little of the abstract principles of open pricing and non-discrimination, and tended to emphasize the detailed arrangements which, it asserted, suppressed fair competition by enforcing uniformity of price and terms in all sugar transactions. The Supreme Court declined to discuss the purposes or the principles of the Sugar Institute abstractly, and laid emphasis on the nature and effect of its operations. The case therefore involves not so much a study of Principles as the economic analysis of the effect of particular trade practices on competition. Since the trade practices involved in the Sugar Institute litigation reappear in the programs of other trade associations, the most effective way to measure the impact of the case on the law, and on the future of the trade association movement, is to consider the outstanding phases of the Sugar Institute program separately.

Price Reporting. The Institute adopted an efficient system of telegraphic price reporting and relaying. Changes were to be announced before three o'clock on the day prior to the effective date, thus giving the refiners time to meet the announced price or otherwise change their own prices. In actual practice, only imminent price rises, and not de- 
clines, were consistently so reported in advance. Notices went back and forth through the Institute at a rapid rate, and almost invariably nightfall found the refiners on the uniform basis price. This worked little change in the customary system of price reporting in the sugar market. But the agreement of the defendants to sell only at the prices publicly announced necessarily meant that the refiners were restrained from deviating from the announced prices. This agreement was rigorously enforced.

Traditionally, sugar has been sold only on "moves"- that is, the movement or sale of a large volume of sugar at the prevailing price in anticipation of an impending advance. These moves have been customarily produced by the announcement of a price advance, whereupon the trade stepped in and purchased the necessary supply at the old price prior to the effective date of the advance. Little sugar is sold upon a decline in price, because the customer is always assured that he will receive prior notice of an advance and can purchase at the low price before the effective date of the advance. Since price advances, and corresponding purchases on moves, occurred about once a month, most sugar was sold during one or two days of the month, under contracts estimated to cover a month's supply. Frequently after a move is provoked, the price sinks back to a lower level. The decree of the trial court forbade concerted maintenance of a future price reporting plan, but did not forbid individual future price announcements or the concerted maintenance of a system of reporting past transactions.

The trial court's decision has been criticized in that "the terms of the decree forbid any plan by which current and future prices or price changes become known to competitors. ${ }^{2155}$ It should be borne in mind that without a concerted plan or contracts to make future prices binding, such a practice has prevailed in the sugar industry for decades. Within a few minutes after an individual price announcement, the news has been flashed from coast to coast-to the refiners, to brokers, to the trade, thus provoking "moves." This usage has continued during the period in which the decree has been operative. The Supreme Court emphasized this "special and historic practice of the sugar industry," of announcing price advances prior to the actual change, and, observing that the trial court did not hold that practice in and of itself illegal, ordered a modification of the decree to permit the Institute to continue the circulation of the future-price announcements.

The Supreme Court's opinion seems to confuse the concerted future price reporting scheme of the Institute with the historic individual price reporting of the pre-Institute sugar market. The sugar refiners could carry on their business by individual future price announcements through the same channels previously used, and could continue the sugar moves,

55. Handler, supra note 1 , at 12 . 
just as they had done for many years prior to the Institute, without the Institute's service in reporting future prices. But the decree as amended by the Supreme Court permits the concerted reporting of future prices, terms, or freight rates, but stipulates that refiners must remain free to deviate from announced prices, and bars the Institute from investigating departures. Few trade association executives could visualize such a scheme as a practical program. To say that a competitor may report a future price which is not a true future price, and that the same competitor, even having reported a truthful price, is entirely free to deviate from it, manifests a touching faith in the capacity of a business man to resist the temptation (a) to take advantage of his competitors, by making secret concessions, or (b) to agree tacitly with his fellow members to abide by the prices and terms announced, and thus produce the restraining influence which the Court seeks to avoid. As the defense said in its brief below:

"To prevent the price openly announced from being a lie and a trap necessitates some machinery which avoids a secret change ...."

The public announcement of prices charged, as they are currently charged, cannot much affect competition and may tend to eliminate secret concessions; but a trader's position is fortified, and his price is stiffened, when he sells with assurance of the continuity of his competitor's price; the inevitable consequence of future-price reporting is to weaken price competition and tempt the industry actually to fix prices; furthermore, future-price reporting without an obligation to adhere to the announced prices clearly invites discrimination.

In the struggle for stabilization, industries have adopted a variety of plans for the exchange of information as to prices and terms. The Court was dealing with plans for the reporting of past transactions in the Hardwood, Maple Flooring and Cement cases. A number of industries, moreover, have taken the additional step and have exchanged information as to future prices. A phase of future price reporting was an essential part of the plan condemned in the Linseed Oil case. If the economic function of future-price reporting in an industry containing few sellers is to make the monopolistic competition of the sellers more intelligently monopolistic, the Sugar Institute case contains a dangerous precedent. For it sanctions a plan of future-price reporting, and other industries may find the rule useful. ${ }^{50}$ It should not be overlooked, however, that in the Sugar Institute case the result was supposed to be justified by historic usage of the industry, and by the special, if somewhat unrealistic, qualifications with which the Supreme Court tried to mitigate this part of the decree. But these qualifications may lose vitality in the future, despite the fact that the various systems for the

56. See Donovan, supra note 1, at 939. 
exchange of future price information, applicable in the different industries, have not yet received blanket judicial approval. The question in the future cases, as in this case, is the degree to which the system is or may be utilized to restrain competition, either alone or in conjunction with supplementary agreements; and it is in connection with this final, generalized test of legality that the use of more precisely formulated economic criteria seems both practical and promising.

The most typical of the plans for future-price reporting now in use contain provisions for the passing of a substantial time between the date of the announcement and the effective date of the new price. The system in the sugar trade is distinguished by (a) future-price reporting, in substance, only on advances; ${ }^{57}$ (b) the custom of repricing on declines to give all customers the lowest price of the day or of a longer past period; (c) the custom of long standing of provoking sugar moves by announcing future price advances. The case may thus be limited to its own peculiar facts, and of this possibility the Chief Justice gave ample notice.

The Sugar Institute opinion hardly makes explicit the general economic objections to future-price reporting; the disapproval of the practice which it expresses is founded on the obvious restraint involved in the members' obligation to adhere to announced prices. But analogous elements symptomatic of a more fundamental restraint of competition will probably appear in many instances of trade-association price reporting. The Linseed Oil case, for example, remains a persuasive deterrent to schemes of future-price reporting which aim too overtly at future-price raising; and the Sugar Institute case itself seems to imply that price-reporting plans with substantial waiting periods and obligatory non-deviation, patterned after the steel code of the NRA, are in the twilight zone. Standing quite alone and without a showing of restraint, future-price reporting may look lawful. But in view of the economic effect of this device, and of others supplementary to it, and in view further of the ease in each case with which more tangible evidence of monopolistic influence can be assembled, industry may be well advised, after the Sugar Institute case, to beware.

Statistical Information. Another phase of the Sugar Institute's work, closely related in function to its future-price reporting, was its activity in procuring and distributing a variety of information relevant to the producer's future conduct. Complete information was collected and made currently available as to prices, rates, terms, and conditions of sale. Members reported each week their melt (production) for the week, total refined stocks on hand, and total deliveries for the week. In tabulated

57. The defense contended in each court that there was no future price reporting. Sce Fact Brief for Defendants 79, in District Court, and Brief for Appellants 62-63, in the Supreme Court. 
form, with individual refiners indicated by key letters, this information was promptly reported back to the members. Figures on total production and total deliveries, but not on individual refiners' production and deliveries, were released to the trade. The total stocks on hand were not reported to the trade. Information as to deliveries, by states, deliveries by differential routes, the amount of sugar stored on consignment, amount in transit, and the capacity of refineries, were reported only to refiners. But the Institute did not collect or pass out information regarding the supply of raws on hand or to arrive. In view of the fact that the raws are imported, this information is pertinent to the question of supply available.

The failure to collect information as to the supply of raws on hand was attributed to the fear of a squeeze in the raw market. A refiner testified that in buying sugar "he does not want to bull the market on himself." A large portion of these transactions had always been secret as to price, because the refiners did not want their competitors to know the "trades" or concessions they were getting. Thus we find a combination insistent upon "open and economic competition" in sales, concluding that it can purchase more advantageously under a secret concession system, when faced with the possibility of the same kind of "perfect" competition in acquiring its raw materials.

The courts could discover no objection in the policy of the anti-trust laws to the dissemination of such information; but they did sense a menace to competition in the fact that the Sugar Institute confined its information service to members, that is, to refiners, and thus, by depriving purchasers of equal knowledge weighted the market in favor of the sellers. ${ }^{58}$ The decree did not forbid the statistical system except to the extent that the information was not made fully and fairly available to the trade. In the view of economic theory, two-sidedness of competition is probably essential to a policy of maximizing the competitive energies of the market, and buyers should be as thoroughly informed as sellers. By requiring that the information be made available to the trade, the decree tends to lessen the disparity in the relative positions of the numerous, small, unorganized purchasers on the one hand, and the small group of powerful sellers on the other. The principle involved seems worth saving, although there is little knowledge as to its actual importance. It may be conjectured that the buyer may use the information in judging when to buy and whom to press for a price reduction, thus in some measure mitigating the sellers' advantage of number and position. But no amount of information can place numerous purchasers on a parity with a few sellers, and the combination of sellers can exploit its control of the industry the more perfectly, the better it is informed as to trade conditions. The fact of this monopolistic power generally under the

58. See United States v. American Linseed Oil Co., 262 U. S. 371 (1923); Chicago Board of Trade v. United States, 246 U. S. 231, 240 (1918). 
Sugar Institute was clear; the extent of its effect was in doubt. Undoubtedly the informational system played an important part in making the Institute's entire scheme of monopolistic entrenchment more effective.

Realistically, the courts recognized the phenomenal fact of trade association growth and attempted more or less pragmatically to curb its most conspicuous dangers. Both on price reporting and on the exchange of statistical information, the Sugar Institute case departs somewhat from the Linseed Oil case, further weakens the position of the Hardwood case, and gives greater vigor to the opinion of the dissenting justices in that case and to the decision of the majority in the Maple Flooring case. But the Sugar Institute case is not carte blanche for trade association statistical services; and if the study of industrial results confirms some of the economist's suspicions, an attack on these seemingly innocent activities may reverse the trend in the cases.

With the increased popularity of informational work by combinations, the problem of protecting the public interest against a potential enhancement of monopolistic competition becomes more urgent. It may be that the circumstances of modern industrial life make the exchange of information an inevitable, if not altogether essential feature of business activity. Insofar as work of this kind represents a desirable trend in business usage it is submitted that the distributing trade and the interests of the public will be best served, and the opportunities for monopolistic advantage minimized, if it is carried on by a neutral agency. For example, a standard reporting and statistical agency might be organized which would not be wholly supported by or under the control of any phase of industry or of any particular industry as a whole. ${ }^{50}$ It might be efficiently equipped to serve numerous industries, including all the branches thereof. The agency should collect statistics and information as to trade conditions in an impartial manner, and disseminate it to the entire trade concerned and to the public. Identity of customers, unnecessary details or needlessly damaging information should not be reported. The agency should be a service agency of highest standing, with no interest in other businesses or in commodities. It should cooperate with government but should not function under governmental control. No meetings of competitors would be essential. Efficiency might thus be at a maximum, while the danger to the public should be at a minimum.

Discrimination. One of the most zealously protested aims of the Sugar Institute was to eliminate price discrimination, in the interests both of making competition more competitive, and business more ethical. The argument of ethics analogized the sugar market to retail trade. In the best type of retail trade, it was contended, price discrimination is not tolerated: that is, similar articles are sold by a trader to all customers similarly situated at the same price. The inference was that discrimina-

59. Cf. Handler, supra note 1 , at 8-9. 
tion among buyers of sugar would be like the bargaining of an oriental bazaar. On the economic level, the Institute argued from the premise that price discrimination doesn't exist in perfect competition; and concluded that if it were eliminated from the sugar markets, the sugar markets would be more perfectly competitive.

Under a regime of considerable competition between numerous sellers, continued price discriminations not justified by differences in cost are well nigh impossible, ${ }^{60}$ and the trader markets the same commodity everywhere at the same basic price, due allowance being made for pertinent differences in transactions. The purchasing trade accepts as proper prices which vary with variations in quantity, service, delivery, containers, and the like. This type of variation in price can hardly be termed a discrimination. Where a seller, however, has sufficient influence in the market to discriminate between buyers, it is a question to be answered out of the experience of each situation whether the net result of monopolistic discrimination is preferable to the social consequence of the non-discriminating monopoly.

There are many occasions when a discriminatory monopolist sells more goods for less money than would be distributed by a monopolist who could sell at one price only. Discrimination by the monopolist may extort a higher than monopoly price from some, whose demand for the product is insistent and inelastic, and it may permit other purchasers who could buy only at a lower than monopoly price to satisfy part at least of their demand. The social danger of unregulated discrimination is notorious, as in the case of local price cutting to destroy competition; but the possible social benefits of discrimination are not so often indicated. And one may infer, from the energy with which the Sugar Institute demanded an end of discrimination, that the consequence of discrimination in the sugar trade had been the sale of more sugar at a lower average price.

Before the Institute was organized, a one-price policy was a glittering fiction in the sugar industry. Sugar was, in the main, a standard commodity, but there were many factors differentiating sugar transactions. Some customers bought little, some much. Deliveries varied in quantity. One customer shipped by barge, while others used the railroads and highways. One took delivery at the refinery, another at his place of business. One accepted large or small quantities by taking a few bags at a time from the various local warehouses of the refiners, while another took delivery in carloads or barge-loads. One customer preserved and returned the bags, another discarded them. One purchaser acted also as broker, warehouseman or transportation company, and was paid therefor; another merely as purchaser. One contracted for a huge quantity delivered over a period of a year, while another bought no more than

60. Efforts for secrecy are not generally effective as a shield for price diseriminations. 
a month's supply. One took deliveries evenly, one irregularly. One customer advertised the refiner's product, another did not.

In the midst of these and other complicating factors, the general overcapacity of the industry bore down on the refiners' price structure, like the head of water at a high dam. Even with a standardized product and a uniform announced basis price, sugar reached the floor of neighboring customers at different prices. Earned discounts led to unearned discounts. It was generally known in the trade that "secret" concessions were given widely and in a variety of forms. What is somewhat uncritically accepted as the rules of equitable trading required the elimination of some of these discounts and concessions. Stability of price structure required the elimination of all. ${ }^{01}$ Such stability could be achieved completely only if real differentials in cost were ignored in the Institute's general price policy, embodied in its two slogans "open prices" and "non-discrimination." This program meant more than agreement on high-sounding principle; the publicity of open prices is an effective part of such a price policy, but not without the supplementary restraining agreements and relentless practical supervision of the second part of the program. Thus we have a modern combination apparently suppressing monopoly's ancient, persistent and most destructive weapon-price discrimination. $^{62}$

But the public fared no better under the new form of monopolistic competition than under the old. The Sugar Institute's aim at standardization of all trading in sugar, implicit in its twin slogan of open prices and non-discrimination, extended to numerous and well enforced supplementary agreements. Refiners could sell at an all-rail delivered price, and ship by water, and impose on purchasers' trade terms and cost items which producers had theretofore accepted. Thus the Institute forbade, inter alia, discounts generally, long-term contracts (the usual contract was thirty days, and prices fluctuated ordinarily at least once a month), used bag returns, refining of customer's raws at a toll price, quantity discounts, etc. It required uniform terms, control over sales of damaged sugar, and sugar which was "frozen" in a community where there was no effective market; distributors were not permitted to perform more than one function; various restrictions were placed on transportation, the use of the transiting privilege, ${ }^{63}$ the shipment of "mixed" commodities, pooling of sugars of several persons in cars or barges, methods

61. FETTER, op. cit. supra note 24 .

62. It has been difficult to wean the oil industry from this device, e. G., see the Pacific Coast Cartel under the NRA Code of Fair Competition for the Petroleum Industry, Pacific Coast Area, as originally framed, November, 1933, which would have enabled the major companies legally to continue this "economy" of the oil industry by selling gasolino under the major brand while peddling the same gasoline through a secret subsidiary under a different brand at a lower price.

63. Much attention was given to transiting-where, e. g., a purchaser orders sugar 
of delivery, etc. The Institute maintained rules to aid in freight equalization and to decrease absorptions. (The California \& Hawiian Sugar Refining Corporation, Ltd. absorbed as much as two to three million dollars in a year in freight charges to reach distant markets.) The Institute, over limited periods and in limited areas, had maintained all-rail basing point, delivered price systems, coupled with refusal to sell f.o.b. refinery.

The trial court found: ${ }^{\text {at }}$

"37. At the inception of the Institute, defendants adopted a general agreement ostensibly to abolish all discriminations between customers but which in general purpose and effect amounted to an agreement not to afiord different treatment to different customers, regardless of the varying circumstances of particular transactions or classes of transactions and regardless of the varying situation of particular refiners, distributors or customers or classes thereof. Under the guise of performing the agreement against discriminations, defendants limited and suppressed numerous important contract terms and conditions in the particulars herein set forth, chiefly for the purpose and with the effect of accomplishing the objectives described in finding 36."

The decree forbade:

"1. Effectuating any general plan to give the same terms, "conditions, or freight applications to customers, regardless of the varying circumstances of particular transactions or classes of transactions or regardless of the varying situation of particular refiners, distributors or customers or classes thereof;"

The legal principle thus established is in line with the opinion of the defense economist, as developed on cross examination, ${ }^{60}$ and is in line with economic opinion generally. Inflexibility of the price structure, such as that here imposed, is a gross imperfection in the price-making mechanism, and only tends to heighten the collective control over the market exercised by the small group of powerful sellers, and entirely to eliminate from competition various key elements in price. Uniformity of price was preserved, but gross discriminations were in fact promoted. An unfettered and disorderly competition would have better served the ends of economic competition. The policy underlying the concrete legal rule laid down by the Trial Court is one of the most important declarations in the Sugar Institute case. For the court's antagonism to schemes of "equalization" which mask discriminations and conceal subsidies of the basing-point type, must curtail many similar trade-association activities

delivered from point $A$ to point $B$, and himself orders shipment continued to point $C$, thus procuring the through rate from $A$ to $C$, and defeating the refiner's delivered price at point $C$.

64. Record 273-274.

65. Supra at 1348-1349. "Much of the profit of the business man, indeed, consists in this still in purchasing on favorable terms; the very essence of usual business practice is this system of different prices to different customers."-Seurgasast, Prnicroles of Eco:ionncs (6th ed. 1914) 149-150. 
and may revitalize the Federal Trade Commission's long, and thus far futile, struggle against such practices.

But it would be inaccurate to conclude that the Sugar Institute case wholly deprives industry of the advantages of a one-price policy. While there are important exceptions to the operation of the law, sellers individually are legally obligated under Section 2 of the Clayton Act to maintain the policy to a substantial extent. ${ }^{08}$ The statute itself takes into account the fact that superficially uniform prices may sometimes violate a true one-price policy. ${ }^{67}$ Thus, if the circumstances in two transactions are so substantially different that different prices are essential to impartial dealing, the fixing of the same price in the two transactions may itself be a violation of the statute. ${ }^{68}$ The basing-point system of delivered prices is an important instance which readily suggests such a situation. ${ }^{69}$

While absolute uniformity in the treatment of customers is not required, the individual may suffer the consequences of Section 2 of the Clayton Act, where the effect of the discrimination may be substantially to lessen competition. And the seller must shoulder the burden of proving that such a discrimination comes within the provisos of the statute permitting certain discriminations based on differences in cost of manufacture, sale, or delivery, resulting from different methods of sale or delivery or quantities sold, or based upon changing conditions affecting the market for or the marketability of the goods. ${ }^{70}$ Presumably the law of trade associations starts with the premises of the Clayton Act, and the cases under it at least permit industry in combination to adopt and maintain for individual members the one-price policy in the several

66. 38 Stat. 730 (1914), 15 U. S. C. A. \$§ 12-27 (1926), as recently amended by P. A. No. 692, approved June 16, 1936; American Can Co. v. Ladoga Canning Co., 44 F. (2d) 763 (C. C. A. 7th, 1930), cert. denied 282 U. S. 899 (1931); Van Camp \& Sons Co. v. American Can Co., 278 U. S. 245 (1929); see McAllister, Sales Policics and Price Discrimination under the Clayton Act (1932) 41 Yale L. J. 518; cf. Storey Parchment Co. v. The Patterson Parchment Paper Co., 282 U. S. 555 (1931), rev'g 37 F. (2d) 537 (C. C. A. 1st, 1930); Mennen Co. v. Federal Trade Comm., 288 Fed. 774 (C. C. A. 2d, 1923), cert. denied 262 U. S. 759 (1923); National Biscuit Co. v. Federal Trade Comm., 299 Fed. 733 (C. C. A. 2d, 1924), cert. denied 266 U. S. 613 (1924); Baran v. Goodyear Tire \& Rubber Co., 256 Fed. 570 (S. D. N. Y., 1918); Comment (1930) 39 YALE L. J. 1035.

67. Cf. McAllister, supra note 66, at 533-534.

68. Even a legislature may be unable to require the same price under such varying conditions. Fairmount Creamery Co. v. Minnesota, 274 U. S. 1 (1927); cf. New York v. Nebbia, 291 U. S. 502 (1934); Goldsmith and Winks, Price Fixing: Nebbia \& Guffey (1936) 31 Irr. L. REv. 179; cf. McAllister, supra note 66, at 538.

69. See the "Pittsburgh Plus" decision, In the Matter of United States Stecl Corp, 8 F. T. C. 1, 52 (1925); cf. FETTER, op. cit. supra note 24 at 322; Comment (1932) 45 HaRv. L. Rev. 548, 553, n. 27.

70. See Van Camp \& Sons Co. v. American Can Co.; American Can Co. v. Ladoga Canning Co., both sutpra note 66, and see McAllister, loc. cit. sttpra note 66 . 
situations where the statute requires it for individuals. If however, the non-discriminatory price policy is aimed at the elimination of what the trade considers unethical and uneconomic price practices, not in themselves clearly in conflict with the policy of the Clayton Act, its legality is much more difficult to predict on the basis of the opinions in the Sugar Institute case. The theory of the anti-trust laws might be interpreted to permit such activity. Thus the Chief Justice stated in the opinion: ${ }^{71}$

"Designed to frustrate unreasonable restraints, they do not prevent the adoption of reasonable means to protect interstate commerce from destructive or injurious practices and to promote competition upon a sound basis. Voluntary action to end abuses and to foster fair competitive opportunities in the public interest may be more effective than legal processes. And cooperative endeavor may appropriately have wider objectives than merely the removal of evils which are infractions of positive law. Nor does the fact that the correction of abuses may tend to stabilize a business, or to produce fairer price levels, require that abuses should go uncorrected or that an effort to correct them should for that reason alone be stamped as an unreasonable restraint of trade. Accordingly we have held that a cooperative enterprise otherwise free from objection, which carries with it no monopolistic menace, is not to be condemned as an undue restraint merely because it may effect a change in market conditions where the change would be in mitigation of recognized evils and would not impair, but rather foster, fair competitive opportunities. Appalachion Conls v. United States, 288 U. S. 344, 372, 374."

The idea that competition may be self-regulated so as to pitch it upon an effective plane is deeply rooted in both economic and legal history. The Clayton Law and the Federal Trade Commission Act impliedly recognize the privilege of business to establish rules of the game. The Board of Trade case, the exceptions from the decree in the Swift case, ${ }^{72}$ and the Cement case furnished judicial precedent for the courts' action in the Sugar case in carving out a field for permissible industrial self-control. That industry can function within this limited field is hardly open to doubt.

The difficulty comes not in reciting the abstract propositions of law or of economic policy but trying to fit them to the confusion of "facts" in a trial record. Clearly, the suggestion made in the Sugar Institute case does not go so far as to encourage elimination of legitimate price differences. The decision of the Court on this point can only mean that legitimate differences of costs shall not be prevented from influencing price. Trade practices aiming to eliminate price discrimination are illegal if they eliminate "fair and useful" competition. They tend to be illegal the more they attempt to bring what is arbitrarily regarded as business ethics into play against the substantial forces of competition.

In the sugar indistry, sauce for the goose is not sauce for the gander.

71. 56 S. Ct. 629, at 641 (1936).

72. Swift \& Co. v. United States, 196 U. S. 375 (1905). 
The large long-term contract of one purchaser, coupled with a loan to the refiner, literally saved the economic life of that refiner, and enabled large numbers of the purchasing public to buy sugar at a saving. To the competing refiners the transaction was vicious and "uneconomic," and competing purchasers complained of the "discriminatory" transaction. To pay one customer for the return of his good used bags is to treat him properly and effect an economy; to pay another customer for the return of useful bags is to join with him in a bad practice. The proper value to be fixed on a large amount of business, spread evenly over a long period, will involve extended and intricate accounting and the equally fundamental but less easily delineated judgment of the parties. One combined customer-warehouseman performs honest and efficient services as a warehouseman, whereas another uses the warehouse as a device to get a discount on his sugar. Elimination of a consignment point may eliminate a degree of waste and yet may inconvenience members of the local purchasing trade, drive "desk jobbers" out of business, and favor a neighboring city where consignment stocks are continued in storage.

These are limited suggestions as to the scores of factual complexities which face industry when it tries to formulate trade practices which will satisfy trade grievances without conflicting with the anti-trust laws. Yet, industry itself is best able to determine the point where a restrictive rule of trade practice impinges on fair competition, and there the law draws the line. Where a competitive practice can, and does on occasions, work fairly and economically in favor of the trade, it will be difficult to justify its sweeping elimination, even though in application the practice results in a measure of unfairness or waste. The interests of the consuming public and of third parties affected by a combination will be viewed sympathetically by the courts, if the mood of the Sugar Institute decision is maintained. Generally, their interest cannot be protected otherwise.

In this article the endeavor has been for the most part to review general aspects of the Sugar Instiute case against the background of earlier trade association decisions and modern economic theory. A subsequent article will analyze more particularly the specific devices employed by the Institute in its comprehensive regulation of competition in the sugar industry. 